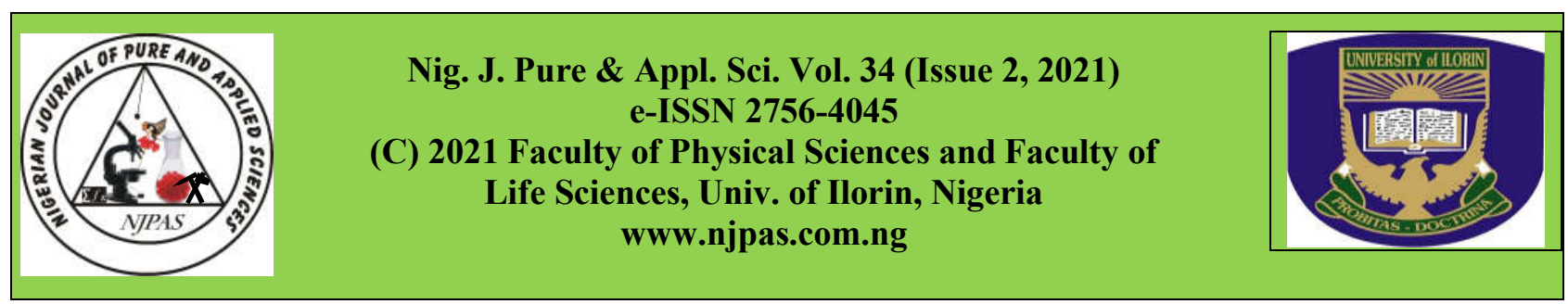

\title{
Hydrocarbon Degrading Potentials and Antibiotic Susceptibility Test of Bacteria Isolated from Amended Soil in Ilorin
}

\author{
*Adetitun, D. O. and Oguntoye, M.B
}

Page | 4072 Department of Microbiology, Faculty of Life Sciences, University of Ilorin, P.M.B. 1515 Ilorin, Kwara State. Nigeria

Date Received: 02-08-2021

Date Accepted: 22-10-2021

DOI: https://doi.org/10.48198/NJPAS/21.B06

\begin{abstract}
This study used bacteria from hydrocarbon-contaminated soil that had been treated. Organic amendments included cassava peels, plantain peels, eggshells, and poultry droppings, while inorganic amendments included NPK and Urea. In this study, three (3) bacteria were characterized and dealt with: Bacillus amyloliquefaciens, Bacillus proteolyticus, and Providencia rettgeri. To determine their biodegradative capabilities, these isolates were tested on a variety of hydrocarbons. In addition, the antibacterial activity of the bacteria was tested in vitro against extracts of Moringa oleifera, Vernonia amygdalina (Bitter leaf), Ocimum gratissimum (Scent leaf), and Telifairia occidentalis (Ugwu) at different concentrations (20\%, 13\%, 10\%, 7\%, and 3\%). Using the maceration procedure, the plant materials were extracted with ethanol and methanol. The bacteria were resistant to the various concentrations of plant extracts, according to the results. The methanolic and ethanolic extracts of Vernonia amygdalina (bitter leaf) had the maximum inhibition zone, measuring $6.00 \pm 0.00 \mathrm{~mm}$. Furthermore, all isolates were resistant to crude oil, engine oil, heptane, and benzene in antimicrobial tests on hydrocarbons, with Bacillus amyloliquefaciens having the highest level of susceptibility $(18 \mathrm{~mm})$ to pyridine. However, the bacteria all demonstrated broad spectrum susceptibility to the commercial antibiotics used as a control, with the exception of Providencia rettgeri, which proved resistant $(5 \mathrm{~mm})$ to Ampiclox (APX), Zinnacef $(\mathrm{Z})$ and Amoxacillin (AM).
\end{abstract}

Keywords: Antimicrobial susceptibility, Biodegradation, Hydrocarbons, Plant extracts, Soil

\section{Introduction}

Petroleum and its by-products pollute the environment as a result of inappropriate waste management, poor effluent and wastewater disposal from companies and dwellings, as well as other man-made activities (Aluko et al., 2018). Oil

discovery and use, fueled by the rapid rate of industrialization and has resulted in increased pollution, which has invariably wreaked havoc on the ecology (Alam et al., 2018). Contaminants build up in the soil, are absorbed by plant roots,

Corresponding Author: Adetitun, D. O.

Department of Microbiology, Faculty of Life Sciences, University of Ilorin, P.M.B. 1515 Ilorin, Kwara State. Nigeria.

Phone: +238036910988; Email: adetitun.do@unilorin.edu.ng 
seep into surface and ground water, and disperse as aerosolized pollutants into the air, all of which are harmful to human and animal health (Ghaemi et al., 2015; Edyta and Dariusz, 2020). Contaminants such as petroleum hydrocarbons and heavy metals

Page | 4073 are extremely harmful to the environment, and human exposure to these dangerous substances can have serious health repercussions as well as change the socioeconomic activities of a community (Umana et al., 2016; Aniefiok and Udo, 2019).

The importance of ecosystem replenishment is gaining attraction around the world. One example is the emphasis on bioremediation of contaminated sites. Microbial actions are used in this procedure, which is a multi-phased process (Adams et al., 2015). Because it does not disrupt or transform the trophic chain in the de-contaminated ecosystem, bioremediation has earned global reputation as an environmentally friendly approach. Contaminants can be converted to simple chemicals by microorganisms, making them non-pollutants (Basheer, 2018). As a result, using bacteria or fungus to break down environmental contaminants has become a practical and economically acceptable strategy for successful biodegradation (Lukasz et al., 2020).

Plants, man, and animals have interacted since the dawn of time as food, shelter, drugs, and oxygen are derived from plants (Hamid et al., 2016; Fonmboh et al., 2020). Phytochemicals such as alkaloids, steroids, flavonoids, saponins, tannins, starch, and other natural bioactive substances present in plants, particularly leaves, stems, roots, and fruits (Rungsung et al., 2015) are widely used in agriculture, used as cures, and used in scientific research. As a result of their natural origins, ease of availability and accessibility in local communities, low cost of purchase and ease of administration, plants particularly those of ethno-pharmacological relevance have achieved international popularity and acceptability (Abdullahi and Mainul, 2020).
As a result, the potential of bacteria isolated from polluted soil to breakdown hydrocarbons is highlighted in this research. This research also aims to determine the significance of plants as antimicrobial agents by demonstrating the basis for their therapeutic use by analyzing antimicrobial susceptibility patterns of selected isolates.

\section{Materials and Methods}

Soil was gathered in clean polythene bags at various sites within the Department of Microbiology, University of Ilorin and sent to the laboratory for further investigation. Before being contaminated with spent engine oil, the soil sample was filtered with a $2 \mathrm{~mm}$ sieve to remove stones, sticks, and other debris. Organic amendments (cassava peels, plantain peels, eggshells, and poultry droppings) were also properly sun-dried, ground with a grinder, and filtered with a $2 \mathrm{~mm}$ sieve. Urea and NPK were used as inorganic additives. Table 1 shows the soil microcosm.

Table 1: Experimental Design of Soil Microcosm

\begin{tabular}{|c|c|}
\hline Treatments & Details of Treatment \\
\hline $\mathbf{A}$ & $100 \mathrm{~g}$ soil $+6 \%$ oil $+12 \%(\mathrm{w} / \mathrm{w}) \mathrm{P}$ \\
\hline B & $100 \mathrm{~g}$ soil $+6 \%$ oil $+12 \%(\mathrm{w} / \mathrm{w}) \mathrm{E}$ \\
\hline $\mathbf{C}$ & 100 g soil $+6 \%$ oil $+12 \%(\mathrm{w} / \mathrm{w}) \mathrm{C}$ \\
\hline D & $100 \mathrm{~g}$ soil $+6 \%$ oil $+12 \%(\mathrm{w} / \mathrm{w})$ PD \\
\hline $\mathbf{E}$ & $100 \mathrm{~g}$ soil $+6 \%$ oil $+12 \%(\mathrm{w} / \mathrm{w}) \mathrm{U}$ \\
\hline $\mathbf{F}$ & $100 \mathrm{~g}$ soil $+6 \%$ oil $+12 \%(\mathrm{w} / \mathrm{w}) \mathrm{N}$ \\
\hline G & $\begin{array}{l}100 \mathrm{~g} \text { soil }+6 \% \text { oil }+6 \%(\mathrm{w} / \mathrm{w}) \mathrm{U}+ \\
\text { all organic amendments }\end{array}$ \\
\hline $\mathbf{H}$ & $\begin{array}{l}100 \mathrm{~g} \text { soil }+6 \% \text { oil }+6 \%(\mathrm{w} / \mathrm{w}) \mathrm{N}+ \\
\text { all organic amendments }\end{array}$ \\
\hline I & $\begin{array}{l}100 \mathrm{~g} \text { soil }+6 \% \text { oil }+4 \%(\mathrm{w} / \mathrm{w}) \text { All } \\
\text { amendments }\end{array}$ \\
\hline $\mathbf{J}$ & $100 \mathrm{~g}$ soil $+6 \%$ oil (Unamended soil) \\
\hline $\mathbf{K}$ & $100 \mathrm{~g}$ soil (Control) \\
\hline
\end{tabular}

Legend: $\mathrm{P}=$ Plantain peels, $\mathrm{E}=$ Eggshells, $\mathrm{C}=$ Cassava peels, $\mathrm{PD}=$ Poultry droppings, $\mathrm{U}=\mathrm{Urea}, \mathrm{N}=\mathrm{NPK}$

To count total heterotrophic bacteria, soil samples from each soil set-up were taken every 14 days for a total of 42 days. 


\section{Plant Collection}

The plant samples (Telfairia occidentalis - Ugwu, Ocimum gratissimum - Scent Leaf, Vernonia amygdalina - Bitter Leaf, and Moringa oleifera) Page | 4074 were collected in Ilorin, Kwara State and identified at the Department of Plant Biology, University of Ilorin. The leaves were washed to eliminate contaminants before being air-dried for 5 days at room temperature and then pulverized using a blender.

\section{Plant Extract Preparation}

A mass of $25 \mathrm{~g}$ of each pulverized plant material was weighed into sterile stoppered volumetric flasks containing $200 \mathrm{ml}$ of $98 \%$ ethanol. The flasks were adequately covered and shaken for five (5) days to ensure continual agitation and homogenization of the contents. The resulting extractant/formulation was filtered with a Whatman No.1 filter paper after passing through a muslin/cheese cloth. The residue was then filtered after being reconstituted in $100 \mathrm{ml}$ of $98 \%$ ethanol. The extract was concentrated in a water bath at 50 ${ }^{\circ} \mathrm{C}$ before being used in the experiment as described by Awe and Omojasola (2003) with slight modifications.

Likewise, the methanolic extraction was also prepared using the aforesaid approach and as explained by Mashiar et al. (2009).

\section{Determination of pH and Phytochemical Screening of Plant Extracts}

The $\mathrm{pH}$ of the extracts was evaluated by calibrating a $\mathrm{pH}$ meter with $\mathrm{pH}$ buffers 4.0 and 7.0 before dipping the $\mathrm{pH}$ probe into the extracts. The average values were recorded after taking duplicate readings. In addition, qualitative screening of both methanolic and ethanolic plant extracts for various phytochemicals was carried out using the methodologies of Mohammed et al. (2014) and Dixon and Jeena (2017).

\section{Isolation, Enumeration and Characterization of Isolates}

A volume of $100 \mu 1$ was measured from the $10^{-4}$ serially diluted soil samples and placed into correctly labeled Petri dishes followed by the addition of sterile molten Nutrient Agar. The plates were allowed to solidify before being inverted and incubated for 24 hours at $37{ }^{\circ} \mathrm{C}$. Following that, using Bergey's Manual of Determinative Bacteriology, the colonies were counted and isolates were properly identified and characterized (Holt et al., 1994). Gram staining was carried out according to the protocol of Fawole and Oso (2007) with minor modifications. Molecular analysis was carried out for proper identification by analyzing the nucleotide sequence codes of the isolates in the National Center for Biotechnology Information (NCBI) database using the BLASTn algorithm.

\section{Assay of Plant Extracts, Hydrocarbon and Antibiotics}

The antibacterial activity of the extracts and the antimicrobial susceptibility of the isolates were evaluated using the agar diffusion method on Mueller Hinton Agar. Using sterile swab sticks, overnight broth cultures of the test organisms were swabbed on solidified sterile Mueller Hinton Agar on Petri dishes. A sterile cork borer was used to cut five (5) circular wells (10 $\mathrm{mm}$ in diameter) in the media. $100 \mu \mathrm{l}$ of the relevant leaf extract concentrations $(20 \%, 13 \%, 10 \%, 7 \%$, and $3 \%)$ were measured and dispensed into correctly labeled Petri dishes using a sterile micropipette. To allow the extracts to thoroughly diffuse into the agar, the plates were left on the workbench for 1 hour. Plates were incubated upright for 24 hours at $37^{\circ} \mathrm{C}$ following which the zones of inhibition were measured to the nearest diameter along two axes of $90^{\circ} \mathrm{C}$ to each other and average values were recorded (Omotayo, 1998).

Using sterile swab sticks, overnight broth cultures of the test organisms were swabbed on sterile Mueller Hinton Agar in Petri dishes. A circular 
ditch was cut in the middle of the plates with a sterile cork borer of $10 \mathrm{~mm}$ diameter. A volume of $70 \mu 1$ of the various hydrocarbons was measured into correctly designated Petri dishes using a sterile micropipette. To allow the hydrocarbons to diffuse Page | 4075 properly into the agar, the plates were left on the workbench for 1 hour. Plates were incubated upright for 24 hours at $37{ }^{\circ} \mathrm{C}$, following which the zones of inhibition were measured to the nearest diameter along two axes of $90{ }^{\circ} \mathrm{C}$ each, and the mean of the results was calculated. The plating was done twice and the average readings were taken.

Standard antibiotic discs impregnated with various antibiotics were used to conduct an antibiotic susceptibility test. Using sterile swab sticks, overnight broth cultures of the test organisms were swabbed on sterile Mueller Hinton Agar in Petri dishes. A ditch was formed in the centre of plates using a sterile cork borer of $10 \mathrm{~mm}$ diameter and $100 \mu \mathrm{l}$ of the extraction solvent (methanol and ethanol) was put into correctly labeled ditches using sterile micropipettes. To allow the extracts to thoroughly diffuse into the agar, the plates were left on the workbench for 1 hour. The antibioticimpregnated discs were then placed on the agar surface with sterile forceps to ensure complete contact with the agar before being incubated at 37 ${ }^{\circ} \mathrm{C}$ for 24 hours. Sensitive (S), moderately sensitive (MS), and resistant (R) inhibition zones were measured to the closest millimeters and recorded.

\section{Statistical Analysis}

Using SPSS 16 software, the group mean and standard deviation (SD) were calculated and significant differences between the groups were evaluated. The statistical significance of the difference between the groups was determined using one-way analysis of variance (ANOVA) and Duncan's multiple range test at a $95 \%$ confidence level for all measurements. $\mathrm{P}$ values $<0.05$ were considered significant.

\section{Results}

Prior to contamination with spent engine oil, physiochemical analysis of the experimental soil and organic amendments revealed that the soil had a $\mathrm{pH}$ of 6.5 and a sandy loam texture when assessed on the textural triangle. The $\mathrm{pH}$ of the organic amendments on the other hand varied depending on their individual contents as shown in Table 2.

As indicated in Table 3, the study counted the number of bacterial colonies obtained from the microcosm setup. On Day 14, plantain peels yielded the greatest bacterial count of $6.11 \pm 0.08$ cfu $\mathrm{ml}^{-1}$ while unamended soil yielded the lowest value of $2.70 \pm 2.36 \mathrm{cfu} \mathrm{ml}^{-1}$ on Day 0 . In addition, soil control values rose from $2.87 \pm 2.50 \mathrm{cfu} \mathrm{ml}^{-1}$ at the end of Day 0 to $4.91 \pm 0.40 \mathrm{cfu} \mathrm{ml}^{-1}$ at the end of Day 42. From the result, the biodegradation of the soil containing plantain peels revealed that the values obtained on Day 0, Day 14, and Day 42 were not significantly different. On Day 28, however, there was a significant difference of 4.63 $\pm 0.51 \mathrm{cfu} \mathrm{ml}^{-1}$. Microbial counts derived from NPK amendment increased from $4.91 \pm 0.38 \mathrm{cfu}$ $\mathrm{ml}^{-1}$ on Day 0 to $5.94 \pm 0.21 \mathrm{cfu} \mathrm{ml}^{-1}$ on Day 28, but then decreased to $4.57 \pm 0.26 \mathrm{cfu} \mathrm{ml}^{-1}$ on Day 42 .

Figure 1 depicts the $\mathrm{pH}$ readings of the plant extracts. The methanolic extract of ugwu $\left(\mathrm{U}_{M}\right)$ had the highest reading of 6.7 , while the ethanolic extract of bitter leaf $\left(\mathrm{B}_{\mathrm{E}}\right)$ had the lowest reading of 6.4. Also, Tables 4 and 5 show the findings of the phytochemical screening of methanolic and ethanolic plant extracts. Only Moringa oleifera extracts contained all phytochemicals (saponins, alkaloids, steroids, phlobatanins, and tannins) whereas, other plant extracts had different phytochemicals. 
Table 2: Physiochemical Analysis of the Experimental Soil and Organic Amendments prior to Contamination

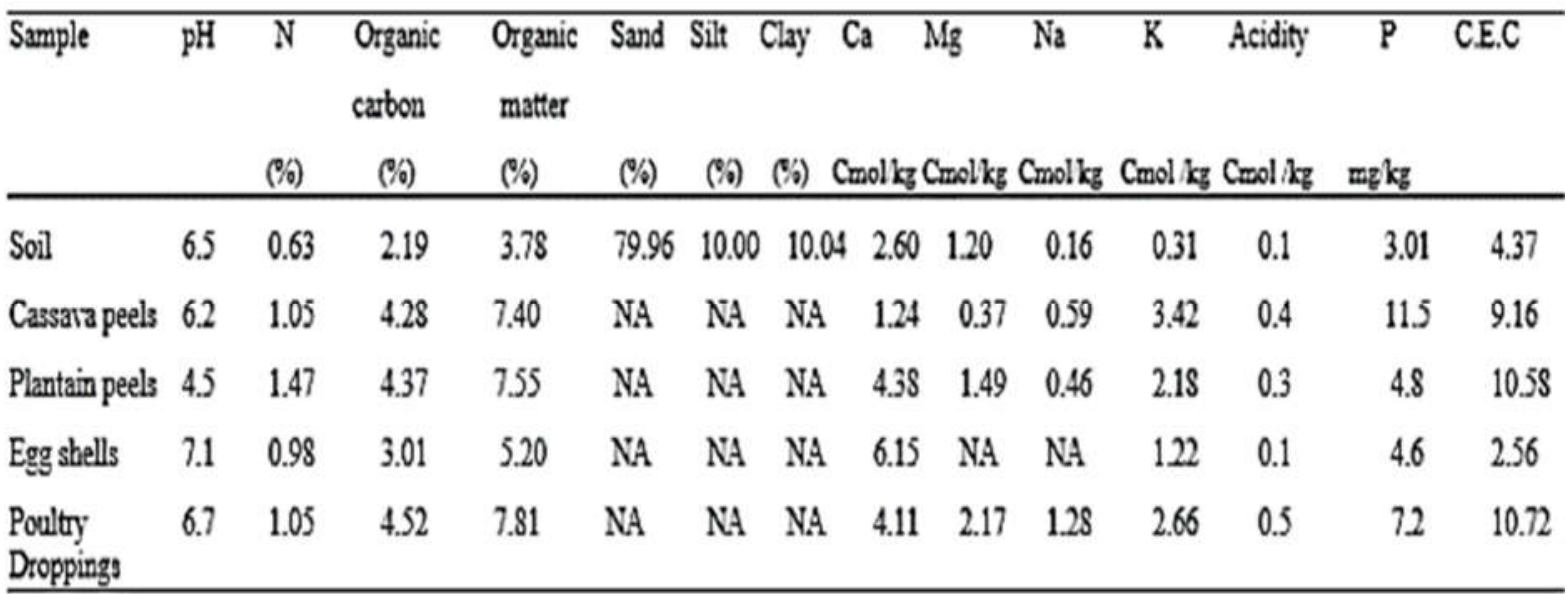

Legend: NA $=$ Not Applicable

Table 3: Enumeration of bacterial counts $\left(\mathrm{Cfu} \mathrm{ml}^{-1}\right.$ in $\left.\log _{10}\right)$ from soil microcosm

\begin{tabular}{|c|c|c|c|c|}
\hline Samples & Day 0 & Day 14 & Day 28 & Day 42 \\
\hline $\mathrm{E}$ & $5.20=0.41^{\mathrm{a}}$ & $5.69 \pm 0.44^{2 b}$ & $5.02 \pm 0.33^{2, b . c}$ & $4.61 \pm 0.19 c d$ \\
\hline $\mathrm{P}$ & $5.15=0.53^{\mathrm{a}}$ & $6.11 \pm 0.08^{2}$ & $4.63 \pm 0.51^{c}$ & $5.53 \pm 0.62^{2}$ \\
\hline C & $5.07=0.37^{\mathrm{a}}$ & $4.13 \pm 2.91^{b}$ & $5.46 \pm 0.49^{2 b, c}$ & $5.02 \pm 0.51^{2 b, c, c d}$ \\
\hline PD & $5.82=0.34^{\mathrm{a}}$ & $6.10 \pm 0.05^{\mathrm{a}}$ & $4.71 \pm 0.31^{c}$ & $5.39 \pm 0.33^{2.6}$ \\
\hline $\mathrm{U}$ & $5.47=0.27^{\mathrm{a}}$ & $5.18=0.68^{\mathrm{ab}}$ & $4.93 \pm 0.33^{2 b, c}$ & $5.50 \pm 0.09^{2}$ \\
\hline $\mathrm{N}$ & $4.91=0.3 \mathrm{~g}^{\mathrm{a}}$ & $5.25 \pm 0.14^{2 a b}$ & $5.94 \pm 0.21^{2}$ & $4.57 \pm 0.26^{d}$ \\
\hline UPE & $5.05=0.67^{\mathrm{a}}$ & $5.90 \pm 0.15^{2 a b}$ & $5.29 \pm 0.62^{2, b . c}$ & $5.35 \pm 0.54^{2 . b}$ \\
\hline NPE & $4.02=0.2 \mathrm{~s}^{\mathrm{ab}}$ & $6.07 \pm 0.19^{\mathrm{a}}$ & $5.25 \pm 0.93^{a b b c}$ & $5.27 \pm 0.19^{2 b . c .}$ \\
\hline$A A$ & $4.10=0.46^{\mathrm{ab}}$ & $5.58 \pm 0.43^{2.6}$ & $5.39 \pm 1.08^{a b b c}$ & $4.73 \pm 0.25^{b . c, d}$ \\
\hline US & $2.70=2.36^{b}$ & $5.42 \pm 0.02^{2 b}$ & $5.81 \pm 0.12^{2 b b}$ & $4.46 \pm 0.25^{d}$ \\
\hline $\mathrm{co}$ & $2.87 \doteq 2.50^{b}$ & $4.89 \pm 0.34^{2 b}$ & $4.84 \pm 0.38^{c}$ & $4.91 \pm 0.40^{2, b . c, d}$ \\
\hline
\end{tabular}

Values represented are means $(n=3) \pm S D$; Values with the same superscript across rows are not significantly different from each other $(\mathrm{P}<0.05)$.

Legend: $\mathrm{E}=$ Eggshells, $\mathrm{P}=$ Plantain peels, $\mathrm{C}=$ Cassava peels, $\mathrm{PD}=$ Poultry droppings, $\mathrm{U}=$ Urea, $\mathrm{N}=$ $\mathrm{NPK}, \mathrm{UPE}=$ Urea + All organic amendments, NPE $=\mathrm{NPK}+$ All organic amendments, AA $=$ All amendments, $\mathrm{US}=$ Unamended soil, $\mathrm{CO}=$ Control soil 


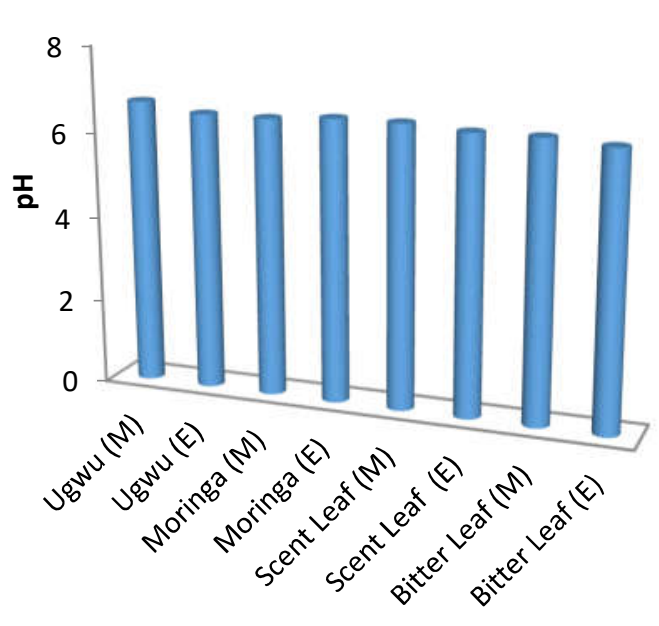

Plant Extracts

\section{Legend: $M=$ Methanol; $E=$ Ethanol}

Figure 1: $\mathrm{pH}$ of Plant Extracts after Methanolic and Ethanolic Extraction

Table 4: Phytochemical Screening of Methanolic Plant Extracts

\begin{tabular}{lllll}
\hline Phytochemicals & Moringa & Ugwu & $\begin{array}{l}\text { Scent } \\
\text { Leaf }\end{array}$ & $\begin{array}{l}\text { Bitter } \\
\text { Leaf }\end{array}$ \\
\hline Saponins & + & + & + & + \\
Alkaloids & + & + & + & - \\
Steroids & + & + & - & - \\
Phlobatannins & + & - & - & - \\
Tannins & + & + & + & +
\end{tabular}

Legend: $+=$ Present; - = Absent

Table 5: Phytochemical Screening of Ethanolic Plant Extracts

\begin{tabular}{lllll}
\hline Phytochemicals & Moringa & Ugwu & $\begin{array}{l}\text { Scent } \\
\text { Leaf }\end{array}$ & $\begin{array}{l}\text { Bitter } \\
\text { Leaf }\end{array}$ \\
\hline Saponins & + & + & + & + \\
Alkaloids & + & + & - & - \\
Steroids & + & + & - & - \\
Phlobatannins & + & - & - & - \\
Tannins & + & + & + & +
\end{tabular}

Legend: $+=$ Present; - = Absent
The results as shown in Figures 2-4, suggested that the plant extracts had low antibacterial activity. Bacillus amyloliquefaciens had the largest zone of inhibition of $5.50 \pm 0.71 \mathrm{~mm}$ in the methanolic and ethanolic extracts of Vernonia amygdalina (bitter leaf) whereas, Bacillus proteolyticus had the highest zone of inhibition of $6.00 \pm 0.00 \mathrm{~mm}$ in the ethanol extract of bitter leaf. Similarly, the methanolic bitter leaf extract inhibited Providencia rettgeri the most with a zone of inhibition of $6.00 \pm 0.00$ $\mathrm{mm}$.

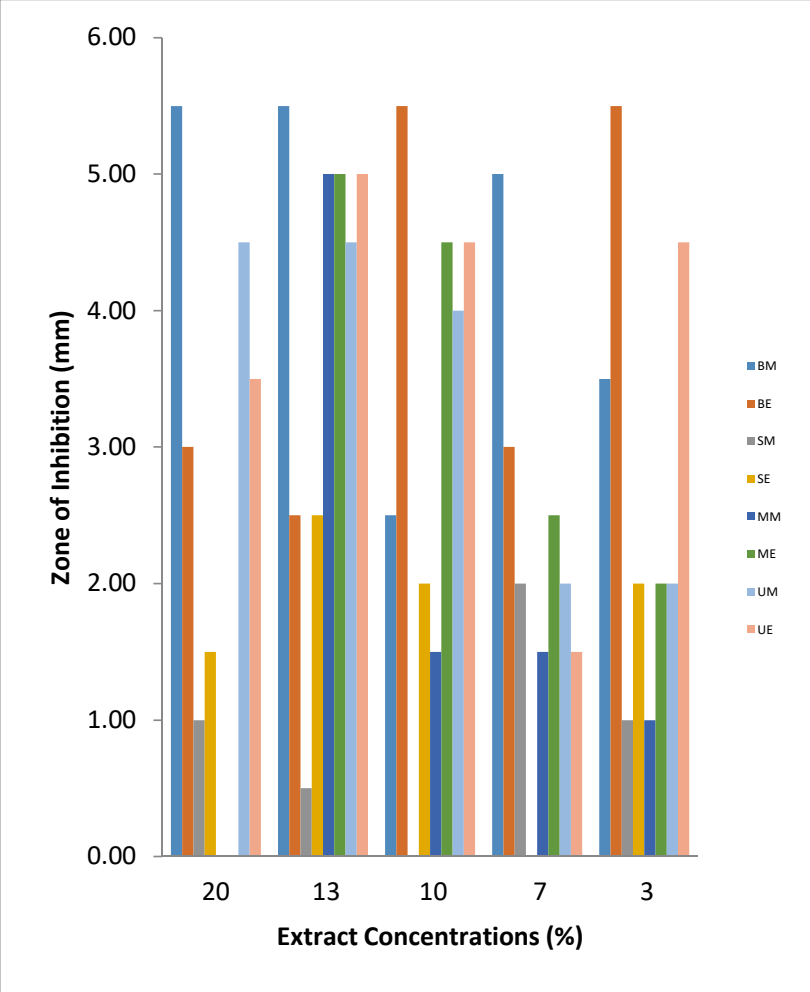

Figure 2: Zone of inhibition of Bacillus amyloliquefaciens on the plant extracts

Legend: $0.0 \mathrm{~mm}$ : No Zone of Inhibition; $>11 \mathrm{~mm}=$ Sensitive (S); 7 $\mathrm{mm}-10 \mathrm{~mm}=$ Moderately Sensitive (MS); $2 \mathrm{~mm}-6 \mathrm{~mm}=$ Resistant (R)

BM - Bitter Leaf (Methanol) $\quad$ MM - Moringa (Methanol) $\mathrm{BE}$ - Bitter Leaf (Ethanol) $\quad \mathrm{ME}-$ Moringa (Ethanol) SM - Scent Leaf (Methanol) UM - Ugwu (Methanol) $\mathrm{SE}-$ Scent Leaf (Ethanol) UE - Ugwu (Ethanol) 


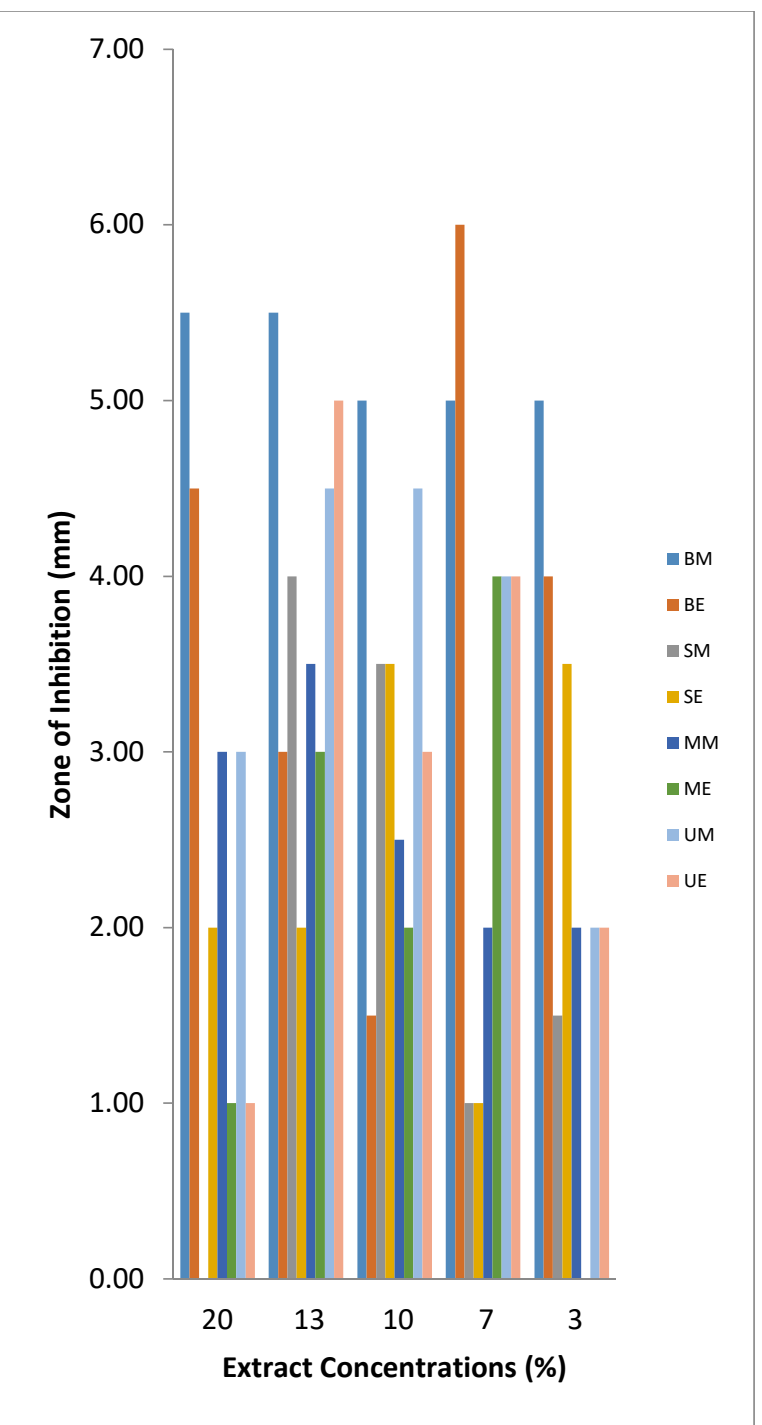

Figure 3: Zone of inhibition of Bacillus proteolyticus on the plant extracts

\section{Legend:}

0.0mm: No Zone of Inhibition; > $11 \mathrm{~mm}=$ Sensitive (S); 7mm$10 \mathrm{~mm}=$ Moderately Sensitive (MS); $2 \mathrm{~mm}-6 \mathrm{~mm}=$ Resistant (R)

BM - Bitter Leaf (Methanol) MM - Moringa (Methanol)

BE - Bitter Leaf (Ethanol) ME - Moringa (Ethanol)

SM - Scent Leaf (Methanol) UM - Ugwu (Methanol)

SE - Scent Leaf (Ethanol) UE - Ugwu (Ethanol)

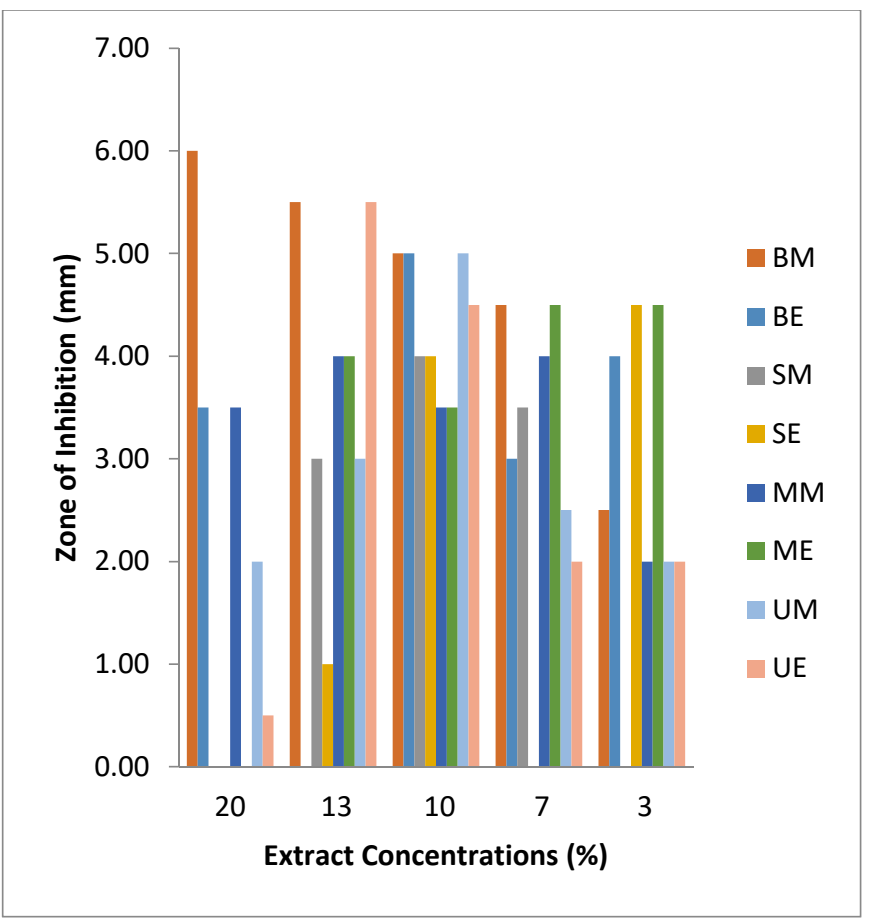

Figure 4: Zone of inhibition of Providencia rettgeri on the plant extracts

\section{Legend:}

0.0mm: No Zone of Inhibition; $>11 \mathrm{~mm}=$ Sensitive $(\mathrm{S}) ; 7 \mathrm{~mm}$ $10 \mathrm{~mm}=$ Moderately Sensitive (MS);2mm-6mm = Resistant (R)

BM - Bitter Leaf (Methanol) MM - Moringa (Methanol)

BE - Bitter Leaf (Ethanol) ME - Moringa (Ethanol)

SM - Scent Leaf (Methanol) UM - Ugwu (Methanol)

SE - Scent Leaf (Ethanol) UE - Ugwu (Ethanol)

Bacillus amyloliquefaciens, Bacillus proteolyticus and Providencia rettgeri were resistant to crude oil, engine oil, heptane, and benzene as shown in Figure 5. However, Bacillus amyloliquefaciens was highly susceptible to pyridine with an inhibition zone of $18 \mathrm{~mm}$, while Bacillus proteolyticus was moderately susceptible to nhexadecane and pyridine with clear zones of $9 \mathrm{~mm}$ and $7 \mathrm{~mm}$ respectively. Providencia rettgeri was moderately susceptible to pyridine with an inhibition zone of $8 \mathrm{~mm}$. 


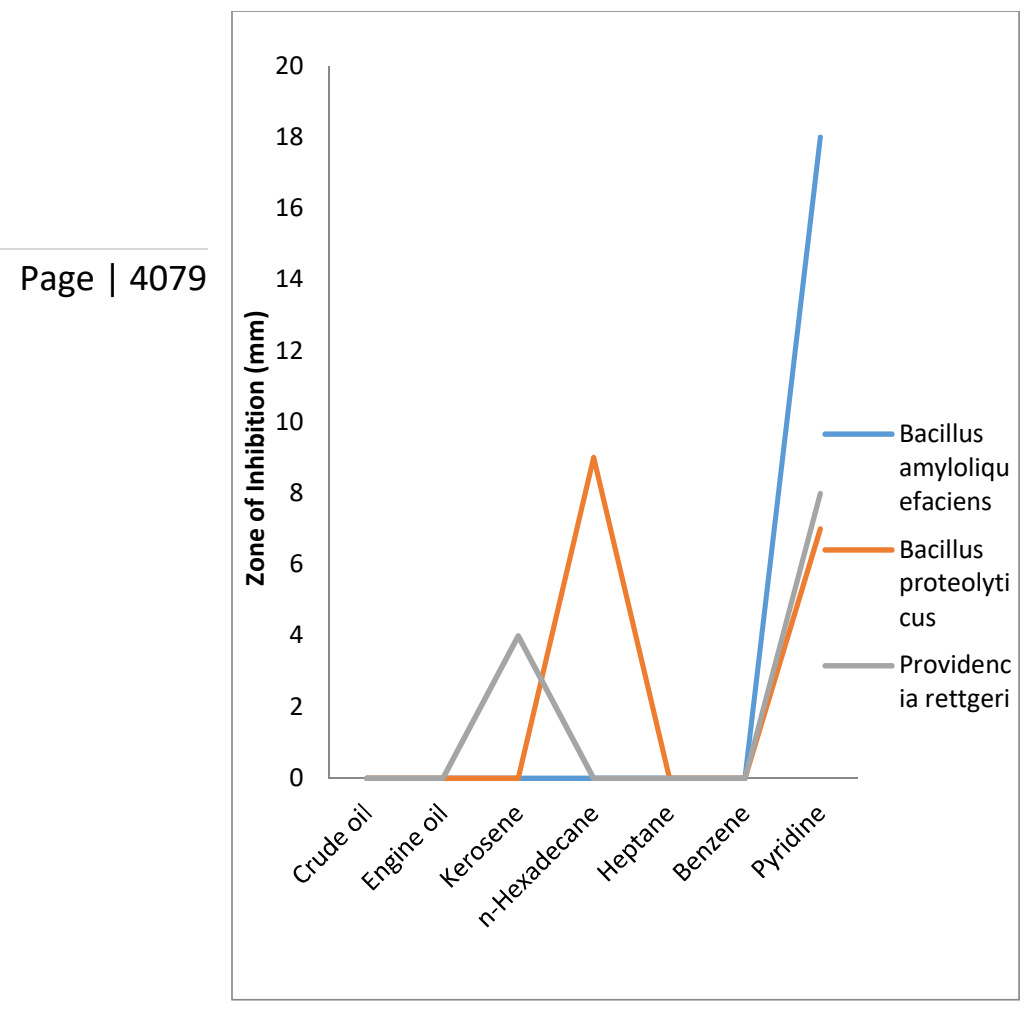

Figure 5: Inhibition zones of isolates on various hydrocarbons

Bacillus amyloliquefaciens and Bacillus proteolyticus were found to be susceptible to Septrin (SXT), Streptomycin (S), Tarivid (OFX), Gentamycin (CN), and Augmentin (AU), among others on Gram-negative discs with a broad spectrum of $20 \mathrm{~mm}$. On Gram-positive discs, they were likewise susceptible to Ciprofloxacin (CPX), Streptomycin (S), Septrin (SXT), Erythromycin (E) and Pefloxacin (PEF) with a broad spectrum of $20 \mathrm{~mm}$. Furthermore, Providencia rettgeri was found to be highly susceptible to all Gramnegative antibiotics, including Chloranphenicol (CH), Sparfloxacin (SP), Amoxacillin (AM), Tarivid (OFX), Gentamycin (CN), Augmentin (AU), Ciprofloxacin (CPX) and others, but showed resistance to antibiotics like Ampiclox (APX), Zinnacef ( $Z$ ) and Amoxacillin as illustrated in Figures 6-9.

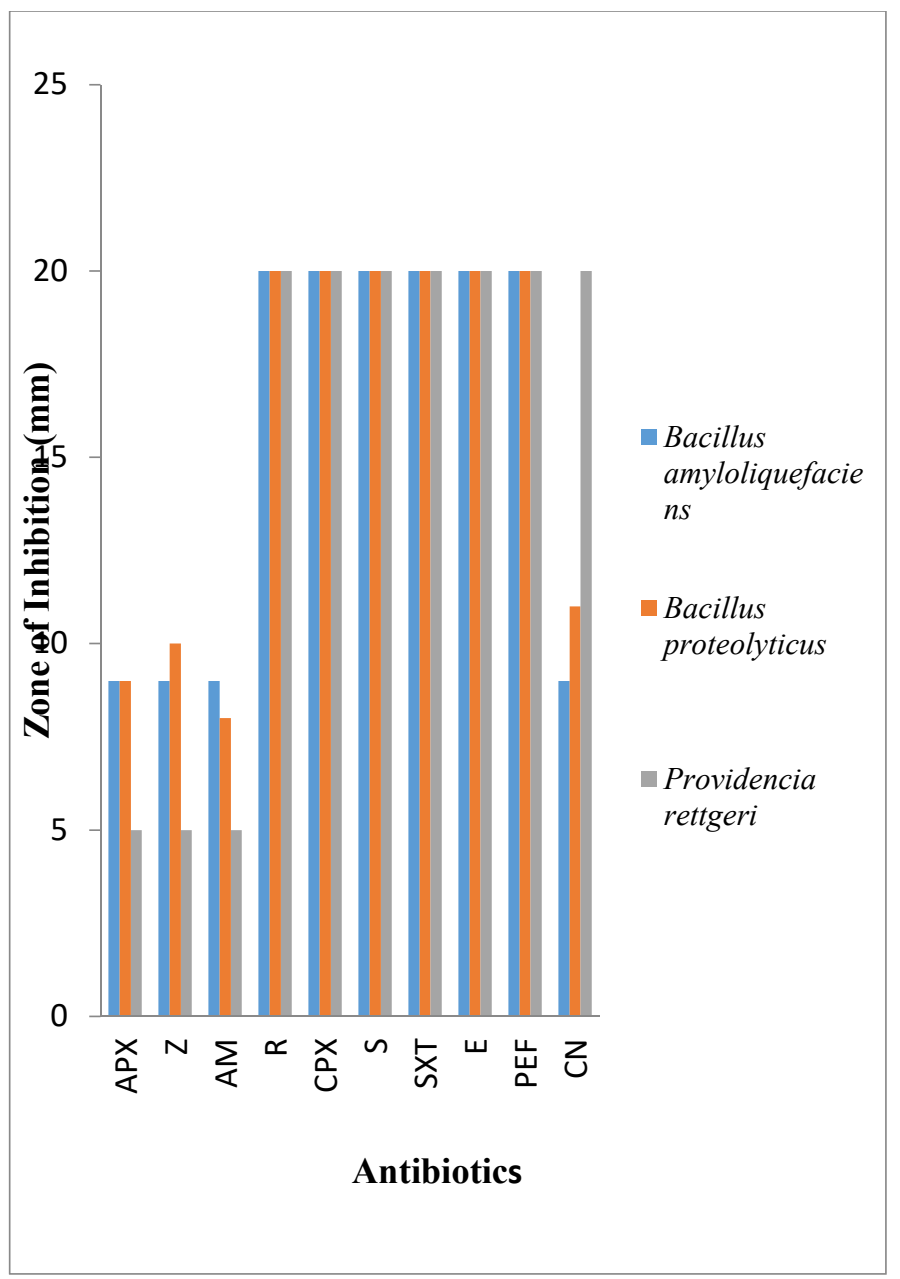

Figure 6: Zone of Inhibition of isolates on Grampositive disc (Methanol)

Legend: $0.0 \mathrm{~mm}$ : No Zone of Inhibition, $>11 \mathrm{~mm}=$ Sensitive $(\mathrm{S}) ; 7 \mathrm{~mm}-10 \mathrm{~mm}=$ Moderately Sensitive (MS); $2 \mathrm{~mm}-6 \mathrm{~mm}$ $=$ Resistant $(\mathrm{R})$

APX - Ampiclox $(30 \mu \mathrm{g}) \quad \mathrm{S}-$ Streptomycin $(30 \mu \mathrm{g})$ Z - Zinnacef $(20 \mu \mathrm{g}) \quad$ SXT - Septrin $(30 \mu \mathrm{g})$ AM - Amoxacillin $(30 \mu \mathrm{g}) \quad$ E - Erythromycin $(30 \mu \mathrm{g})$ $\mathrm{R}-$ Rocephin $(25 \mu \mathrm{g}) \quad$ PEF - Pefloxacin $(10 \mu \mathrm{g})$ CPX - Ciprofloxacin $(10 \mu \mathrm{g}) \mathrm{CN}-$ Gentamycin $(10 \mu \mathrm{g})$ 


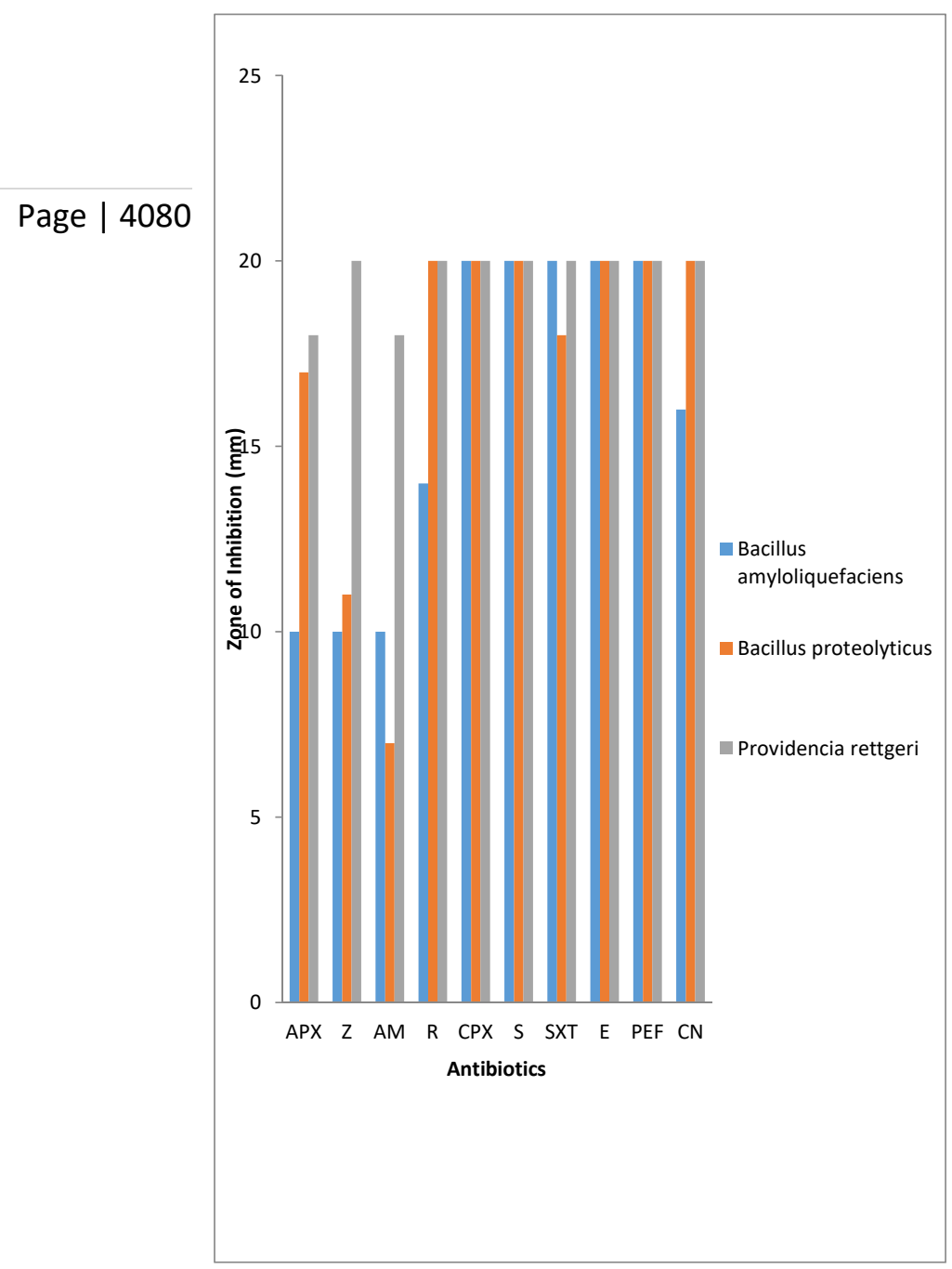

Figure 7: Zone of Inhibition of isolates on Grampositive disc (Ethanol)

Legend: $0.0 \mathrm{~mm}$ : No Zone of Inhibition, $>11 \mathrm{~mm}=$ Sensitive (S); $7 \mathrm{~mm}-10 \mathrm{~mm}=$ Moderately Sensitive (MS); $2 \mathrm{~mm}-6 \mathrm{~mm}$ $=$ Resistant $(\mathrm{R})$

APX - Ampiclox $(30 \mu \mathrm{g})$

$\mathrm{Z}-$ Zinnacef $(20 \mu \mathrm{g})$

$\mathrm{S}-$ Streptomycin $(30 \mu \mathrm{g})$

AM - Amoxacillin $(30 \mu \mathrm{g}) \quad$ E - Erythromycin $(30 \mu \mathrm{g})$

$\mathrm{R}-$ Rocephin $(25 \mu \mathrm{g}) \quad$ PEF - Pefloxacin $(10 \mu \mathrm{g})$

CPX - Ciprofloxacin $(10 \mu \mathrm{g}) \mathrm{CN}-$ Gentamycin $(10 \mu \mathrm{g})$

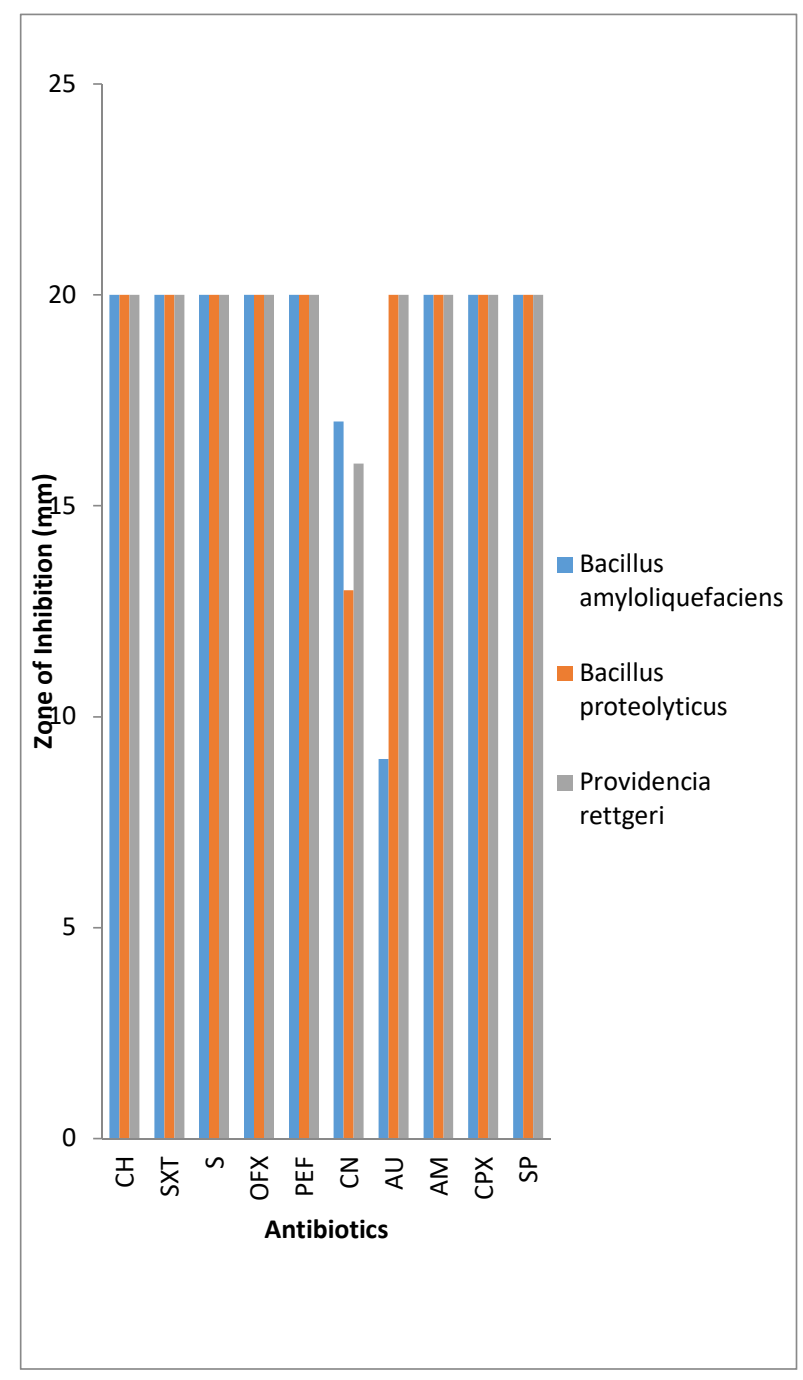

Figure 8: Zone of Inhibition of isolates on Gramnegative disc (Methanol)

Legend: $0.0 \mathrm{~mm}$ : No Zone of Inhibition, $>11 \mathrm{~mm}=$ Sensitive (S); $7 \mathrm{~mm}-10 \mathrm{~mm}=$ Moderately Sensitive (MS); $2 \mathrm{~mm}-6 \mathrm{~mm}$ $=$ Resistant $(\mathrm{R})$

$\mathrm{CH}$ - Chloranphenicol $(30 \mu \mathrm{g}) \mathrm{CN}-$ Gentamycin $(30 \mu \mathrm{g})$

SXT - Septrin $(30 \mu \mathrm{g}) \quad$ AU - Augmentin $(10 \mu \mathrm{g})$

$\mathrm{S}-$ Streptomycin $(30 \mu \mathrm{g}) \quad \mathrm{AM}-$ Amoxacillin $(30 \mu \mathrm{g})$

OFX - Tarivid $(10 \mu \mathrm{g}) \quad$ CPX - Ciprofloxacin $(30 \mu \mathrm{g})$

$\mathrm{PEF}-$ Pefloxacin $(30 \mu \mathrm{g}) \quad \mathrm{SP}-$ Sparfloxacin $(10 \mu \mathrm{g})$ 
Page | 4081

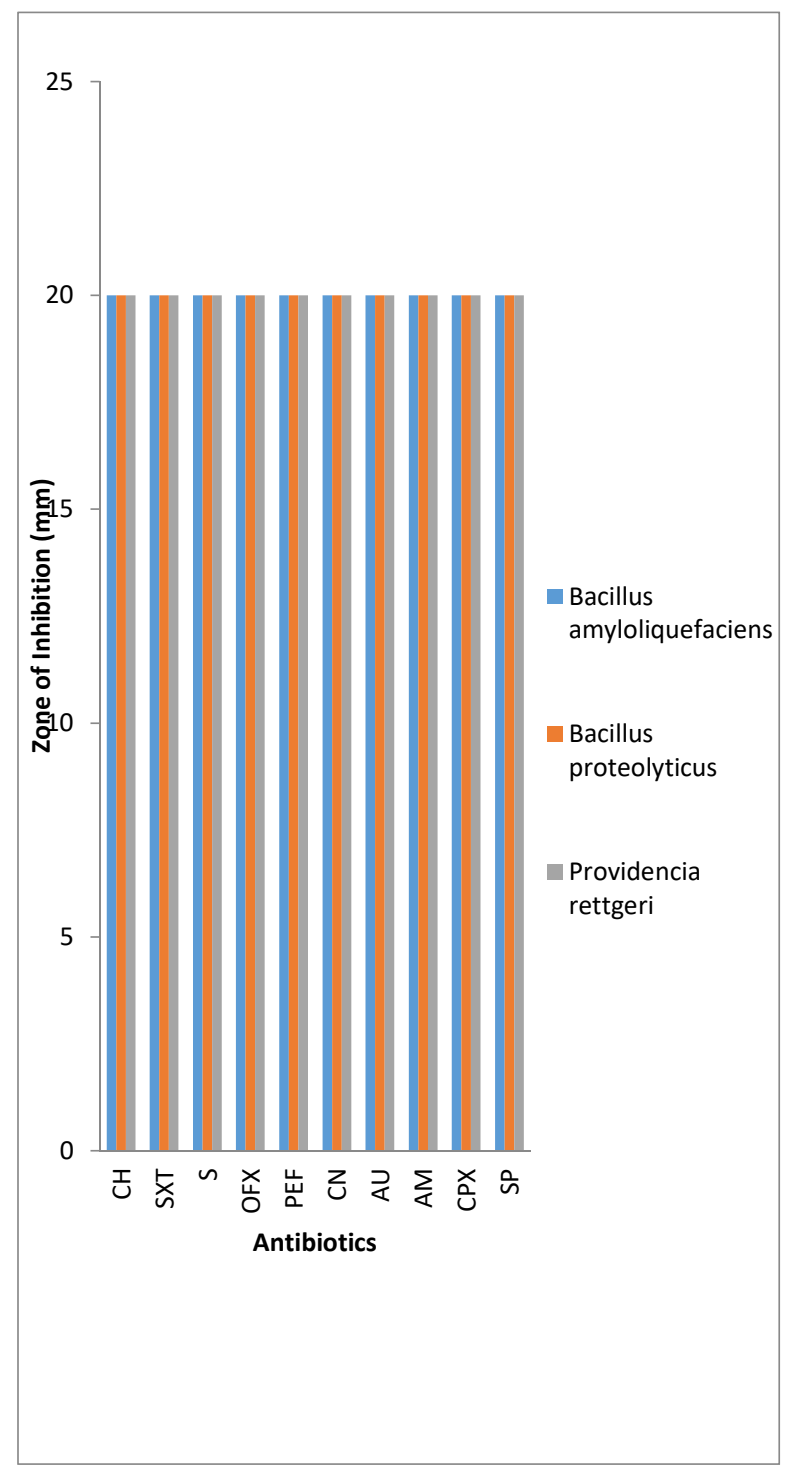

Figure 9: Zone of Inhibition of isolates on Gramnegative disc (Ethanol)

$\begin{array}{lc}\begin{array}{l}\text { Legend: } 0.0 \mathrm{~mm} \text { : No Zone of Inhibition, }>11 \mathrm{~mm}=\text { Sensitive }(\mathrm{S}) ; 7 \mathrm{~mm}-10 \mathrm{~mm} \\ =\text { Moderately Sensitive (MS); }\end{array} & 2 \mathrm{~mm}-6 \mathrm{~mm}=\text { Resistant }(\mathrm{R}) \\ \text { CH - Chloranphenicol }(30 \mu \mathrm{g}) & \mathrm{CN}-\text { Gentamycin }(30 \mu \mathrm{g}) \\ \text { SXT - Septrin }(30 \mu \mathrm{g}) & \mathrm{AU}-\text { Augmentin }(10 \mu \mathrm{g}) \\ \mathrm{S}-\text { Streptomycin }(30 \mu \mathrm{g}) & \mathrm{AM}-\text { Amoxacillin }(30 \mu \mathrm{g}) \\ \text { OFX - Tarivid }(10 \mu \mathrm{g}) & \mathrm{CPX}-\text { Ciprofloxacin }(30 \mu \mathrm{g}) \\ \text { PEF -Pefloxacin }(30 \mu \mathrm{g}) & \mathrm{SP}-\text { Sparfloxacin }(10 \mu \mathrm{g})\end{array}$

\section{Discussion}

Mineral nutrients must be available for bioremediation processes to take place, thereby, necessitating the use of biostimulation. Bacterial growth must have been aided by the additional nutrients included in the amendments utilized in this study. When the results from Table 2 were compared to those from earlier studies, they revealed some similarities. Ogunjobi and Ekanem (2017) measured soil pH (6.9), eggshell pH (7.4), and plantain peel $\mathrm{pH}$ (6.9) while Agamuthu et al. (2013) measured soil $\mathrm{pH}$ (5.75) and cow dung $\mathrm{pH}$ (7.00). Vidali (2001) recommended a $\mathrm{pH}$ range of 6.5 to 8 for the breakdown of hydrocarbon oils. For Nitrogen, Phosphorus, and Carbon, Ogunjobi and Ekanem (2017) found similar results of 0.81 $\%, 0.67 \%$, and $1.22 \%$ respectively. Agamuthu et al. (2013) on the other hand, achieved varied concentrations of $0.15 \%, 8.02 \%$, and $4.33 \%$ for these parameters. The results of the nitrogen content of plantain peels and eggshells is in accordance with the observation of Ogunjobi and Ekanem (2017) who recorded $1.22 \%$ and $0.62 \%$ respectively while Agamuthu et al. (2013) recorded $0.54 \%$ as nitrogen content in cow dung. The presence of various nutritional components in the amendments facilitated the enrichment of the soil and might have prompted the biodegradative abilities of the isolates.The microbial counts derived from NPK rose from Day 0 to Day 28 according to the enumerated bacterial colonies obtained from the microcosm set up displayed in Table 3. A related work carried out by Ogunjobi and Ekanem (2017) reported NPK to exhibit higher biodegradation efficiency. In contrast, Agarry and Jimoda (2013) had a lower NPK fertilizer efficiency than a combination of all organic amendments (plant residues and animal dung) applied. The capacity of aboriginal microorganisms to degrade crude oil polluted soil by biostimulation was established in a study by Hamoudi-Belarbi et al. (2018) using carrot peels. Furthermore, Ofoegbu et al. (2014) discovered that combining inorganic fertilizers with cow 
dung additives improved biodegradation. Agbor et al. (2019) and Ekpobari et al. (2019) conducted further studies that corroborated these findings. It was concluded from this investigation that certain amendments when employed singly or in Page | 4082 combination, might greatly improve bioremediation. Rather than being disposed of indiscriminately causing an ecological nuisance and harming the aesthetics of the environment, numerous organic amendments can be studied and exploited for bioremediation.

According to Figure 1, the $\mathrm{pH}$ values obtained from the methanolic and ethanolic plant extracts were similar with the highest value of 6.7 recorded in the methanolic extraction of Ugwu $\left(\mathrm{U}_{\mathrm{M}}\right)$ and the lowest value of 6.4 in the ethanolic extraction of Bitter leaf $\left(\mathrm{B}_{\mathrm{E}}\right)$. The influence of acidity or alkalinity on the efficiency of popular antiseptic compounds was examined by Wiegand et al. (2015). The result obtained revealed a low $\mathrm{pH}$ range of 5.0 to 9.0 for chorhexidine and octenidine. Also, a low pH effectively inhibited microbial growth while antimicrobial effects reduced with a rise in $\mathrm{pH}$. This shows that the acidic $\mathrm{pH}$ obtained in this study may be responsible for the presence and stability of phytochemicals in plant extracts (Mohamed et al., 2015).

The existence of bioactive substances of therapeutic importance was discovered in the phytochemical screening of the plant extracts (Tables 4 and 5). Ethanol and methanol, according to Alara et al. (2020) are organic solvents capable of freeing phytochemicals such as tannins, alkaloids, saponins, flavonoids and other compounds. The findings of this study revealed that the extraction solvents were unable to liberate some of the screened phytochemicals as steroids were absent in both the scent and bitter leaf extracts, phlobatannins were absent in all leaf extracts except Moringa and alkaloids were absent in both the bitter and scent leaf extracts (ethanol extraction). Adetitun et al. (2013) discovered saponins, tannins, flavonoids, phlobatannins, terpenoids, and alkaloids in Moringa oleifera leaves. Also, saponins, tannins, and alkaloids were discovered in scent leaf methanolic extracts but only flavonoids were present in the chloroform extracts while other phytochemicals were lacking according to the study of Umar et al. (2019). Similarly, OladosuAjayi et al. (2017) discovered that Vernonia amygdalina and Ocimum gratissimum contained different phytochemical substances when they were exposed to different extraction solvents. Plant species, plant part, plant growth conditions (soil, water, and temperature), geographical location, season of plant collection, polarity of the solvent and absorbent nature of the plant matrix may all influence the presence or lack of particular phytochemicals in plants (Umar et al., 2019).

The results in Figures 2-4 showed that the plant extracts had little antibacterial activity. This explains why Gram-positive bacteria (Bacillus amyloliquefaciens and Bacillus proteolyticus) and Gram-negative bacteria (Providencia rettgeri) were all resistant. The limited effectiveness of the plant extracts in influencing the zones of inhibition of Bacillus amylolequefaciens and Bacillus proteolyticus could be related to Bacillus spp. resistant endospores. Also, the capacity of Providencia rettgeri to display resistance to antimicrobial compounds in the plants may be due to the formation of lipase from fatty carbon sources which may have hampered the entry of antimicrobial contents into the cell wall. Masud Rana et al. (2014) investigated the antibacterial susceptibility of methanolic extracts of Terminalia chebula (bark), Phyllanthus acidus (fruits), Sarcochlamys pulcherrima (leaves), and Abelmoschus esculentus (fruits) all of which had low activity against Gram-negative bacteria but were effective against Gram-positive bacteria. Similarly, Nigussie et al. (2021) found that the methanol extract of Lawsonia inermis leaves had high antibacterial activity against Staphylococcus aureus, Escherichia coli, Klebsiella pneumoniae, 
Pseudomonas aeroginosa, Shemanella alage and Streptococcus pyogenes while the same methanol extract of Achyranthus aspera revealed low antimicrobial activity on all tested isolates except Streptococcus pyogenes.

Gram-negative bacteria are known to be more resistant to antibiotics than Gram-positive bacteria. This is due to differences in cell wall composition which prevent many ambient chemicals from entering. Gram-negative bacteria when compared to Gram-positive bacteria have higher antibiotic resistance due to the existence of phospholipid membranes with lipopolysaccharide components. This prevents antibacterial compounds from passing through (Taye et al., 2011; Leach, 2015). Low antimicrobial activity of plant extracts can be caused by the inability of the antimicrobial compounds to diffuse adequately into the agar which can be caused by the volume of inoculum in the agar well or the duration of the diffusion phase prior to incubation (Eloff, 2019).

The antimicrobial susceptibility test on hydrocarbons revealed that the isolates were resistant and susceptible to the various hydrocarbons tested as shown in Figure 5. Their ability to grow well on hydrocarbons and use them as carbon and energy sources demonstrates their resistance. When compared to the findings of Thamer et al. (2013), it was discovered that resistant endospores of Bacillus spp. allow them to tolerate high levels of oils which explains why Bacillus amyloliquefaciens and Bacillus proteolyticus grew well on crude oil, engine oil, kerosene, nhexadecane, heptane, and benzene. Furthermore, many hydrocarbon-degrading bacteria have been found to make the best use of hydrocarbons by creating biosurfactants. Bacillus spp. have shown to be capable of producing lipopeptide-derived surfactants, making them useful in the cleanup of hydrocarbon-contaminated locations (Chen et al., 2015).

Furthermore, Providencia spp. are known to produce lipase from lipid carbon sources (usually natural oils), which stimulates their enzymatic degradation of petroleum hydrocarbons (Osho and Alabi, 2020). This could have influenced the tolerance of Providencia rettgeri to crude oil, engine oil, n-hexadecane, heptane, and benzene (Osho and Alabi, 2020). Adetitun et al. (2019) reported that Alcaligenes sp. strain 3k could grow effectively on kerosene and hexadecane and use them as carbon sources but, that it could not break down hexane. Rhodococcus opacus R7 was also described by Zampolli et al. (2014) as having the ability to biodegrade decane and hexadecane but not hexane or octane.

Genes, antibiotic strength, antibiotic concentration and other factors can influence the sensitivity or resistance of bacteria to antibiotics. The organisms had extensive clearance zones to the majority of antibiotics according to the results of the zones of inhibition shown in Figures 6 - 9 . Fiedler et al. (2019) discovered that Bacillus cereus strains were sensitive to Ciprofloxacin, Erythromycin, Gentamycin, Tetracycline, and Chloramphenicol among other antibiotics. Bacillus cereus was clearly resistant to Erythromycin, Tetracycline and $\beta$-lactamase antibiotics according to a divergent view on susceptibility explained by Luna et al. (2007) and Kim et al. (2015) whereas, Bacillus cereus was clearly resistant to Amoxil, Streptomycin and Ampiclox according to Ataikiru et al. (2020). BamHI is a restriction enzyme produced by Bacillus amyloliquefaciens, Barnase - a protein antibiotic is also produced by it (Molohon et al., 2011). Bacillus amyloliquefaciens has a symbiotic relationship with plants and has been found to produce bacillaene and macrolactin among other antibiotics. Bacillus amyloliquefaciens is beneficial as a biological pest-control agent because these compounds protect the host plant from infection by other microbes (Chowdhury et al., 2015; Fan et al., 2017). 
Treatment of Providencia rettgeri has been difficult due to its antibiotic resistance. Certain strains of Providencia rettgeri have been shown to be resistant to Ceftriaxone and Cefepime (Zhou et al., 2014). Also, Aibinu et al. (2011) reported a

Page | 4084 case of Quinolone resistance in Nigeria. The bacterium is also resistant to antimicrobials such Ciprofloxacin, Cephalosporins, and Ampicillin based on the studies of Magiorakos et al. (2012) and Shin et al. (2018). Furthermore, resistant genes can be found on the same plasmid in bacteria and can be easily transported to the environment according to Wiedenbeck and Cohan (2011) and Oyetibo et al. (2010).

\section{Conclusion}

Given the impact of hydrocarbon contamination on the ecosystem and the necessity to clean up contaminated places, bioremediation solutions can be considered. This research looked into the ability of some microorganisms to breakdown petroleum hydrocarbons. Furthermore, all of the isolates showed promise in terms of bioremediation abilities, indicating that they might be used as either indigenous or exogenous microorganisms to aid in the environmentally friendly cleanup of petroleum hydrocarbons and derivatives. In addition, the plants studied in this research had a significant number of bioactive chemicals that can help prevent pathogen invasion and strengthen the immune system. Furthermore, since the microorganisms were discovered to be antibiotic-resistant, antibiotics can be used to combat a variety of diseases connected with them.

\section{Competing Interest}

The authors declare no competing interests

\section{References}

Abdullahi, R.A. and Mainul, H. (2020). Preparation of medicinal plants: Basic extraction and fractionation procedures for experimental purposes. Journal of
Pharmacy and Bio-allied Sciences, 12(1), 1-10.

Adams, G.O., Fufeyin, P.T., Okoro, S.E. and Ehinomen, I. (2015). Bioremediation, Biostimulation and Bioaugmentation: A Review. International Journal of Environmental Bioremediation and Biodegradation, 3(1), 28-39.

Adetitun, D.O., Araoye, H.K., Akinyanju, J.A. and Anibijuwon, I.I. (2013). The antimicrobial effects of the leaf extracts of Moringa oleifera on selected clinical bacterial isolates. Agrosearch, 13(1), 95113.

Adetitun, D.O., Fathepure, B., Hugh, H., Kolawole, O.M. and Olayemi, A.B. (2019). Degradation of hydrocarbons and ligninlike compounds by Alcaligenes sp. strain 3k isolated from Ilorin. Pollution, 5(2), 269277.

Agamuthu, P., Tan, Y.S. and Fauziah, S.H. (2013). Bioremediation of hydrocarbon contaminated soil using selected organic wastes. Procedia Environmental Sciences, 18:694-702.

Agarry, S.E. and Jimoda, L.A. (2013). Application of carbon-nitrogen supplementation from plant and animal sources in in situ soil bioremediation of diesel oil: Experimental Analysis and Kinetic Modeling. Journal of Environment and Earth Science, 3(7), 2224-3216.

Agbor, R.B., Ekpo, A., Antai, S.P., Okpako, E.C. and George, U.M. (2019). Enhancement of bioremediation and rehabilitation of spent engine oil impacted soil. International Journal of Biological Sciences and Research, 2(2), 75-82.

Aibinu, I.E., Pfeifer, Y., Ogunsola, F., Odugbemi, T., Koenig, W. and Ghebremedhin, B. 
(2011). Emergence of $\beta$-lactamases OXA10, VEB,-1, and CMY in Providencia spp. from Nigeria. Journal Antimicrobial Chemotherapy, 66:1931-1932.

Page | 4085 Alam, A.R., Hossain, A.B.M., Hoque, S. and Chowdhury, D.A. (2018). Heavy metals in wetland soil of greater Dhaka District, Bangladesh. Pollution, 4(1), 129-141.

Alara, O.R., Abdurahman, N.H. and Olalere, O.A. (2020).Ethanolic extraction of flavonoids, phenolics and antioxidants from Vernonia amygdalina leaf using two-level factorial design. Journal of King Saud UniversityScience, 32:7-16.

Aluko, T., Njoku, K., Adesuyi, A. and Akinola, M. (2018). Health risk assessment of heavy metals in soil from the iron mines of Itakpe and Agbaja, Kogi State, Nigeria. Pollution, 4(3), 527-538.

Aniefiok, E.I. and Udo, J.I. (2019). Role of plants and microbes in bioremediation of petroleum hydrocarbon contaminated soils. International Journal of Environmental Bioremediation and Biodegradation, 7(1), 1-19.

Ataikiru, T.L., Okorhi-Damisa, F.B. and Onyegbunwa, A.E. (2020). Hydrocarbon biodegradation and antibiotic sensitivity of microorganisms isolated from an oil polluted site in Kokori, Delta State, Nigeria. Issues in Biological Sciences and Pharmaceutical Research, 8(2), 43-50.

Awe, S. and Omojasola, P.F. (2003). Antimicrobial screening of three medicinal plants used for diarrhea treatment in Ilorin, Nigeria. Nigerian Journal of Pure and Applied Science, 18:1375-1379.

Basheer, A.A. (2018). Chemical chiral pollution: Impact on the society and science and need of the regulations in the $21^{\text {st }}$ century. Chirality, 30(4), 402-406.

Chen, M., Xu, P., Zeng, G., Yang, C., Huang, D. and Zhang, J. (2015). Bioremediation of soils contaminated with polycyclic aromatic hydrocarbons, petroleum pesticides, chlorophenols and heavy metals by composting: Applications, Microbes and Future Research Needs. Biotechnology Advances, 33:745-755.

Chowdhury, S.P., Hartmann, A., Gao, X. and Boriss, R. (2015). Biocontrol mechanism by root-associated Bacillus amyloliquefaciens FZB42 - A Review. Frontiers in Microbiology, 6:780.

Dixon, D. and Jeena, G. (2017). Comparision of different solvents for phytochemical extraction potential from Datura metel plant leaves. International Journal of Biological Chemistry, 11:17-22.

Edyta, H. and Dariusz, G. (2020). Hydrophysical properties of sandy clay contaminated by petroleum hydrocarbon. Environmental Science and Pollution Research, 27:96979706.

Ekpobari, N., Nkwocha, E.E. and Oguzie, E.E. (2019). Effectiveness of NPK fertilizer-saw dust amended on biodegradation of crude oil in polluted soil. International Journal of Advances in Scientific Research and Engineering, 5(5), 56-67.

Eloff, J.N. (2019). Avoiding pitfalls in determining antimicrobial activity of plant extracts and publishing the results. $B M C$ Complementary and Alternative Medicine, 19:106.

Fan, B., Blom, J., Klenk, H-P. and Borriss, R. (2017). Bacillus amyloliquefaciens, Bacillus velezensis, and Bacillus siamensis form an "Operational Group $B$. 
amyloliquefaciens" within the B. subtilis species complex. Frontiers in Microbiology, 8:22.

Fawole, M.O. and Oso, B.A. (2007). Laboratory Page | 4086 Manual of Microbiology. In: Spectrum Books Limited, Ibadan, Nigeria. pp. 11-16.

Fiedler, G., Schneider, C., Igbinosa, E.O., Kabisch, J., Brinks, E., Becker, B., Stoll, D.A., Cho, G-S., Huch, M. and Franz, C.M.A.P. (2019). Antibiotics resistance and toxin profiles of Bacillus cereus group isolates from fresh vegetables from German retail markets. BMC Microbiology, 19:250.

Fonmboh, D.J., Abah, E.R., Fokunang, T.E., Herve, B., Teke, G.N., Ngono, M.R., Borgia, N.N., Fokunang, L.B., Banin, N.A., Nubia, K., Ngameni, B. and Fokunang, C.N. (2020). An overview of methods of extraction, isolation and characterization of natural medicinal plants products in improved traditional medicine research. Asian Journal of Research in Medical and Pharmaceutical Sciences, 9(2), 31-57.

Ghaemi, Z., Karbassi, A., Moattar, F., Hassani, A. and Khorasani, N. (2015). Evaluating soil metallic pollution and consequent human health hazards in the vicinity of an industrialized zone. Case study of Mubarakeh steel complex, Iran. Journal of Environmental Health Science and Engineering, 13(2), 1-9.

Hamid, A.A., Oguntoye, S.O., Alli, S.O., Akomolafe, G.A., Aderinto, A., Otitigbe, A., Ogundare, A.M., Esinniobiwa, Q.M. and Aminu, R.O. (2016). Chemical composition, antimicrobial and free radical scavenging activities of Grewia pubescens. Chemistry International, 2(4), 254-261.

Holt, J.G., Kreig, N.R., Sneath, P.H.A., Stanley, J.T. and William, S.T. (1994). Bergey's Manual of Determinative Bacteriology.
Baltimore, USA: Williams and Wilkins. pp.213.

Hamoudi-Belarbi, L., Hamoudi, S., Belkacemi, K., Nouri, L'H., Bendifallah, L. and Mohamed, K. (2018). Bioremediation of polluted soil sites with crude oil hydrocarbons using carrot peel waste. Environment, 5:124.

Kim, C.W., Cho, S.H., Kang, S.H., Park, Y.B., Yoon, M.H., Lee, J.B., No, W.S. and Kim, J.B. (2015). Prevalence, genetic diversity and antibiotic resistance of Bacillus cereus isolated from Korean fermented soybean products. Journal of Food Science, 80:123128.

Leach, L.C. (2015). Structural elucidation of some antimicrobial constituents from the leaf latex of Aloe. BMC Complementary and Alternative Medicine, 15(270), 1-7.

Łukasz, Ł., Marta, W-K., Andreas, P.L., Hermann, J.H. and Łukasz, C. (2020). Microbial degradation of hydrocarbons Basic principles for bioremediation: A Review. Molecules, 25(4), 856.

Luna, V.A., King, D.S., Gulledge, J., Cannons, A.C., Amuso, P.T. and Cattani, J. (2007). Susceptibility of Bacillus anthracis, Bacillus cereus, Bacillus mycoides, Bacillus psedomycoides and Bacillus thuringiensis to 24 antimicrobials using sensititre automated microbroth dilution and Etest agar gradient diffusion methods. Journal of Antimicrobial Chemotheraphy, 60(3), 555-567.

Mashiar, M., Mominal, I., Sharma, A., Soriful, I., Atikur, R., Mizanur, R. and Alam, M. (2009). Antibacterial activity of leaf juice extracts of Moringa oleifera against some human pathogenic bacteria. Journal of Natural Sciences, 8(2), 219-227. 
Masud Rana, S.M., Mustashsan Billah, M.D., Hossain, S.M., Saifuddin, A.K.M., Azizul Islam, S.K.M., Banik, S., Naim, Z. and Raju, G.S. (2014). Susceptibility of microorganism to selected medicinal plants Page | 4087 in Bangladesh. Asian Pacific Journal of Tropical Biomedicine, 4(11), 911-917.

Mohamed, A.C., Jawhar, H., Christophe, R., Didier, L-C and Hatem, M. (2015). Effect of $\mathrm{pH}$ during extraction on the antioxidant and antiglycated activities of polysaccharides from Opuntiafiscus indica. Journal of Food Biochemistry, 40(3), 316325.

Mohammed, S.A., Sanni, S., Ismail, A.M., Kyari, A.S., Abdullahi, S. and Ibrahim, A. (2014). Preliminary phytochemical and elemental analysis of aqueous and fractionated pod extracts of Acacia nilotica (Thora mimosa). Veterinary Research Forum, 5(2), 95-100.

Molohon, K.J., Melby, J.O., Lee, J., Evans, B.S., Dunbar, K.L., Bumpus, S.B., Kelleher, N.L. and Mitchell, D.A. (2011). Structure determination and interception of biosynthetic intermediates for the plantazolicin class of highly discriminating antibiotics. ACS Chemical Biology, 6(12), 1307-1313.

Magiorakos, A.P., Srinivasan, A., Carey, R.B., Carmeli, Y., Falagas, M.E., Giske, C.G., Harbarth, S., Hindler, J.F., Kahlmeter, G., Olsson-Liljequist, B., Paterson, D.L., Rice, L.B., Stelling, J., Struelens, M.J., Vatopoulos, A., Weber, J.T. and Monnet, D.L. (2012). Multidrug-resistant, extensively drug-resistant and pandrugresistant bacteria: An international expert proposal for interim standard definitions for acquired resistance. Clinical Microbiology and Infection, 18(3), 268-281.
Nigussie, D., Davey, G., Legesse, B.A., Fekadu, A. and Makonnen, E. (2021). Antimicrobial activity of methanol extracts of the leaves of three medicinal plants against selected bacteria isolated from wounds of lymphoedema patients. BMC Complementary Medicine and Therapies, 21:2.

Omotayo, A.E. (1998). Antibacterial activity of some antimalarial plants. Proceeding of the Nigerian Society for Microbiology, 39:6972 .

Ofoegbu, R.U., Momoh, Y.O.L. and Nwaogazie, I.L. (2014). Bioremediation of crude oil contaminated soil using organic and inorganic fertilizers. Journal of Petroleum and Environmental Biotechnology, 6:198.

Ogunjobi, A.A. and Ekanem, J.O. (2017). Biodegradation of spent lubricating engine oil in soil using organic and inorganic amendments. Nigerian Journal of Science, 51(2), 109-119.

Oladosu-Ajayi, R.N., Dienye, H.E., Ajayi, C.T. and Erinle, O.D. (2017). Comparative screening of phytochemical compounds in scent leaf (Ocimum gratissimum) and bitter leaf (Vernonia amygdalina) extracts. Journal of Fisheries and Livestock Production, 5:242.

Osho, M.B. and Alabi, M.A. (2020). Biodegradation potential of tropical hydrocarbon degrading Providencia stuartii. Trends in Applied Sciences Research, 15(3), 253-259.

Oyetibo, G., Ilori, M., Adebusoye, S., Obayori, O. and Amund, O. (2010). Bacteria with dual resistance to elevated concentrations of heavy metals and antibiotics in Nigeria contaminated system. Environmental Monitoring Assessment, 168:305-314. 
Rungsung, W., Ratha, K.K., Dutta, S., Dixit, A.K. and Hazra, J. (2015). Secondary metabolites of plants in drugs discovery. World Journal of Pharmaceutical Research, 4: 604-613.

Shin, S., Jeong, S.H., Lee, H., Hong, J.S., Park, M-J. and Song, W. (2018). Emergence of multidrug-resistant Providencia rettgeri isolates co-producing NDM-1 carbapenemase and PER-1 extended spectrum $\beta$-lactamase causing a first outbreak in Korea. Annals of Clinical Microbiology and Antimicrobials, 17:20.

Taye, B., Giday, M., Animut, A. and Seid, J. (2011). Antibacterial activities of selected medicinal plants in traditional treatment of human wounds in Ethiopia. Asian Pacific Journal of Tropical Biomedicine, 1(5), 370375.

Thamer, M., Al-Kubaisi, A.R., Zahraw, Z., Abdullah, H.A., Hindy, I. and AbdKhadium, A. (2013). Biodegradation of Kirkuk light crude oil by Bacillus thuringiensis. Northern of Iran National Science, 5:865-873.

Umana, E.J., Akwaji, P.I. and Markson, A.A. (2016). Bioremediation of spent engine oil contaminated soil by using fungus, Penicillium spp. International Letters of Natural Sciences, 59:82-91.

Umar, M., Nkemelu, C.P., Sagir, M.R., Mohammed, S.Y., Ajiya, G.K., Mohammed, A.B., Yaya, A.A., Kigbu, A.A., Ojo, S.A., Abdulkarim, I.M., Tafinta, I.Y. and Amuta, I.C. (2019). Evaluation of phytochemical, antimicrobial activities and toxicological analysis of scent leaf (Ocimum gratissimum L.) leaf extracts. Asian Journal of Research in Medical and Pharmaceutical Sciences, 7(3), 1-11.

Vidali, M, (2001). Bioremediation: An Overview. Pure and Applied Chemistry, 73(7), 11631172.

Wiedenbeck, J. and Cohan, F.M. (2011). Origins of bacterial biodiversity through horizontal genetic transfer. FEMS Microbiology Ecology, 35:957-976.

Wiegand, C., Abel, M., Ruth, P., Elsner, P. and Hipler, U.C. (2015). pH influence on antibacterial efficacy of common antiseptic substances. Skin Pharmacology and Physiology, 28:147-158.

Zampolli, J., Collina, E., Lasagni, M., and Di Gennaro, P. (2014). Biodegradation of variable- chain-length n-alkanes in Rhodococcus opacus R7 and the involvement of an alkane hydroxylase system in the metabolism. AMB Express, $4(73), 1-9$.

Zhou, G., Guo, S., Luo, Y., Ye, L., Song, G., Guo, L., Chen, Y., Han, L. and Yang, J. (2014). NDM-1 producing strains, family Enterobacteriaceae in hospital, Beijing, China. Emerging Infectious Diseases, 20:340-342. 